Disponível em:

http://editora.unoesc.edu.br/index.php/race

Race, Joaçaba, v. 15, n. 2, p. 447-474, maio/ago. 2016

\title{
GENDER INEQUALITY IN ACCOUNTING PROFESSION FROM THE PERSPECTIVE OF THE GLASS CEILING
}

Desigualdade de gênero na profissão contábil sob a perspectiva do glass ceiling

Júlio César Silva

E-mail: profjuliosilva72@gmail.com

$\mathrm{PhD}$ in Accounting and Business Administration at Regional University of Blumenau; Master in Production Engineering at Federal University of Santa Catarina; Professor in Business Management at the Regional University of Blumenau. Contact address: Rua Antônio da Veiga, 140, Itoupava Seca, 89012-900, Blumenau, Santa Catarina, Brasil.

Cristian Baú Dal Magro

E-mail: cristianbaumagro@gmail.com Master in Accounting at Regional University of Blumenau; PhD student in Accounting and Business Administration at Regional University of Blumenau.

Marcia Zanievicz da Silva

E-mail: marciaza@gmail.com

$\mathrm{PhD}$ in Accounting and Business Administration at Regional University of Blumenau; Master of Accounting at Federal University of Santa Catarina; Professor of the Graduate Program in Accounting at the Regional University of Blumenau.

Article received on March $3^{\text {rd }}$ 2016. Accepted on April 12 2016. 
Abstract

Among the studies developed on gender differences in occupations, the theoretical glass ceiling approach has been used internationally to explain the occurrence of barriers that hinder and even prevent the professional growth of women and generate wage inequalities between men and women in the performance of similar functions. Given the above, the study aims to identify gender differences in the accounting profession analyzed from the perspective of the glass ceiling. The research methodology is descriptive, documentary and the approach is quantitative. Data were extracted from the Annual Social Information (RAIS), base year 2013. The investigated population are employees who work in accounting in companies located in southern Brazil. The results indicate that the professions of accounting auditor and accountant are performed, most often by male professionals. It was found that men have higher pay and a predominance of men in the accounting department of larger companies. We conclude that glass ceiling is present in the accounting profession, creating an invisible barrier to women's access to positions of greater evidence of the accounting profession.

Keywords: Glass Ceiling. Gender. Accounting Professional. Inequality.

\section{Resumo}

Entre os estudos desenvolvidos sobre desigualidade de gênero em ocupações, a abordagem teórica do Glass Ceiling tem sido utilizada internacionalmente para explicar a ocorrência de barreiras que dificultam e até mesmo impedem o crescimento profissional e geram desigualdades salariais entre homens e mulheres que desempenham funções similares. Face ao exposto, o estudo tem como objetivo identificar as desigualdades de gênero na profissão contábil, analisadas a partir da perspectiva do Glass Ceiling. A metodologia da pesquisa é descritivo, documental e a abordagem é quantitativa. Os dados foram extraídos da Informação Anual Sociais (RAIS), ano-base 2013. A população investigados são os empregados que trabalham em contabilidade em empresas localizadas no sul do Brasil. Os resultados indicam que as profissões de auditor de contas e contabilista são realizadas, na maioria das vezes por profissionais do sexo masculino. Verificou-se que os homens têm salários mais elevados e uma predominância de homens no departamento de contabilidade de grandes empresas. Concluímos que teto de vidro está presente na profissão contábil, criando uma barreira invisível para o acesso das mulheres a posições de maior evidência da profissão contábil.

Palavras-chave: Teto de vidro. Gênero. Profissional de contabilidade. Desigualdade.

\section{INTRODUCTION}

In the last decades in Brazil the entry rate of women in the labor market was higher than the entry of men. From 1980 to 1990, 6.3\% women entered the labor 
market, while men showed a rate of 0.7\%. Thus, in the mid-1990s women now represent $35.6 \%$ of the economically active population (OLIVEIRA, 1993).

Also, if recorded increase in female participation on the total of people with a college degree surpassing the male contingent. The National Research by Household Sampling (INSTITUTO BRASILEIRO DE GEOGRAFIA E ESTATÍSTICA, 2013) identified a quota of 7.5 million students in higher education, with 55\% held by women.

The inclusion of women in the labor market has not yet been consolidated. Some problems arising from gender inequality still hindering women in certain careers: lower wages compared to men; double work shift, which affect the association between professional and personal life; deficiencies in public policies; lower chances of professional training in more profitable areas; and lack of opportunity in positions of power (CARREIRA; AJAMIL; MOREIRA, 2001).

Despite of recurrent gender equality speech, practice shows incompatibilities in high labor hierarchies (STEIL, 1997). In accounting, authors like, Earnest and Lampe (1982), Dahl and Hooks (1984), Cheramy and Hooks (1988) had already called attention to the prejudice against women. Pillsbury, Capozzoli and Ciampa (1989) evidenced that female accountants suffer lack of mobility in career advancement explained by men's domain in certain functions of accounting. Similarly, Trapp, Hermanson and Turner (1989) found that male accountants have greater career advancement for accounting management positions, strategic and audit functions.

Historically, women have been excluded from senior positions in the accounting profession (ROBERTS; COUTTS, 1992) occupying a greater number of secretarial functions and general services (MCKEEN; RICHARDSON, 1998). Gender inequality was driven by the fact that women were considered intellectually incapable of performing management functions (LEHMAN, 1992). Recently, it has been seen that women accountants are still fewer in number in upper levels of the hierarchy, while recruitment for operating activities in accounting is increasingly balanced for gender equality (DAMBRIN; LAMBERT, 2008).

On the other hand, according to Gomes (2005) the new reality of the working world has demanded professionals with objectivity, perseverance and willingness to work in teams. Such factors may facilitate the inclusion of women in male-dominated professions. However, in the concept of Cavalcanti and Guimarães (1999), Guimarães (2001) and Brighenti, Jacomossi and Silva (2015) the difference in income between men and women is also growing. This difference is most apparent in power functions being called by the literature as the glass ceiling phenomenon. The glass ceiling is a 
barrier that prevents the growth of women's income because of the exclusion from high positions in the hierarchy and even among management positions.

There is national and international research exploring the glass ceiling, but little is known about its occurrence in the accounting profession. For this reason, the following research question was explored: what are the gender differences in the accounting profession analyzed from the perspective of the glass ceiling? To answer this question the study aims to identify gender differences in the accounting profession analyzed from the perspective of the glass ceiling.

The study is justified by the growing entry of women into the labor market, increasing discussions about gender inequality in career progression (STEIL, 1997). For Munhoz (2000) the invisible barriers that prevent the rise of women in leadership positions are enhanced by the women's stereotype created spreading they would not have leadership style, demonstrating a lack of comprehensive understanding of the business world and excessive care with family.

The choice of the accounting profession is justified by its relevance in decision-making organizations and focus on a single business area, factors favoring the evaluation of aspects of career development (MELAMED, 1995). In addition, research in accounting has relevance in the fact that it is a profession with high workload and excessive hours, factors that make it difficult for women to combine work with family life and care with family.

Additionally, studies of gender inequality on different perspectives contribute to broaden the debate and the search for actions to reduce and therefore help with socialization (HOFFMAN, 2004). Regarding the study by Brighenti, Jacomossi and Silva (2015) this research extends the vision of gender inequality, not only focused on salary issues, but entering the invisible barriers that prevent women to join the most prestigious careers in the accounting profession. Regarding the study by Sousa, Voese and Abbas (2015), the differential has been assessing gender inequality by the employment of women in the accounting profession at different hierarchical levels contributing to the theoretical and empirical field on the effectiveness of glass ceiling.

\section{THEORETICAL BACKGROUND}

The studies developed by Avelino Júnior (2005) and Cardoso, Souza and Almeida (2006), highlighted the increasing participation of women in the accounting profession, however, men still predominate in management positions and accounting leadership, and also get higher pay. However, Cardoso, Souza and Almeida (2006) 
have signaled an increased demand for undergraduate courses in accounting by women while in specialization courses the predominance of men remained.

In the same direction, the study by Siqueira et al. (2013) on the role of women in the accounting environment shows that women's participation has evolved over the last decade, mainly due to the increased entry of women in undergraduate courses. However, even with the growing entry of women trained in accounting, mostly still perform accounting assistant activities, which consequently are less paid than management, leadership and audit positions.

Similarly, Altoe (2014) studied factors that explain the work-life balance for Paraná accountants. The findings indicated that accountants believe that excessive hours of work reflect negatively in other spheres impacting the perception of work-life balance. The factors may explain the evidence that positions that female accountants in Paraná carry out are of accounting assistant and accounting analyst. These findings infer that the lower the hierarchical level the higher the performance of women in accounting.

Historically, the inclusion of women in the labor market is marked by progress and delays. On one hand, there was an increase in female participation in the labor market, with access to careers and prestigious professions, and in management positions. On the other hand, there is high unemployment of women, poor quality of work and the predominance in precarious, informal and assistant activities (BRUSCHINI, 2007).

In Brazil the wage differentials in the labor market have been studied by Cavalcanti and Guimarães (1999), Guimarães (2001) and Brighenti, Jacomossi and Silva (2015). The converging results are based on the support that the differences in average income of women against the men are significant even in the face of research in regions, periods and different timelines. Additionally, reinforcing that age and education can determine the extent of discrimination against women, entering aspects that go beyond the wage gap.

The study by Cavalcanti and Guimarães (1999), by linking education, remuneration and gender found that the returns to education are positive and growing along the income scale in both genders. However, returns to studying grow faster for men than for women. The consequence is that investments in education do not imply better income distribution.

Traditionally, the vast majority of leadership positions in both the United States and in other parts of the world were occupied by men (STELTER, 2002). Even though there is a growing number of women that enter the labor market and an increa- 
se in the number of management positions, women's access to leadership positions remains limited (BLACK; ROTHMAN, 1998; EAGLY; JOHANNESEN-SCHMIDT; VAN ENGEN, 2003; OAKLEY, 2000; RIDGEWAY, 2001; STELTER, 2002). Oakley (2000) argues that there are three categories that explain the barriers that result in the glass ceiling: (1) corporate practices, such as recruitment, retention and promotion; (2) behavioral and cultural causes, such as stereotypes and preferred leadership style; and (3) structural cultural explanations rooted in feminist theory.

According to Meyerson and Fletcher (2000), a woman could miss a promotion to a male colleague with less experience only because of gender discrimination. However, today, these issues should occur less frequently due to the awareness of organizations for the placement of women in high-ranking positions.

Today, discrimination against women remains in a multitude of work practices and cultural norms that seem impartial (MEYERSON; FLETCHER, 2000). Thus, discrimination against women can also occur in the accounting profession. The same may occur with respect to the glass ceiling where women may have more difficulties in the rise of accountant/audit career by the aspects and characteristics related to gender inequality.

Brighenti, Jacomossi and Silva (2015) investigated gender inequality in the performance of accountants and auditors in the labor market of the State of Santa Catarina, Brazil. The survey sample comprised 6,861 professionals in Accounting and Audit of the State of Santa Catarina. The results showed that even women with average range of education equal to that of men, the average pay is still lower, suggesting gender inequality evidence. Regarding the influencing factors of compensation the age of attributes, length of employment, education and company size were similar between men and women actually confirming that wage inequality comes from the gender discrimination.

In France, there was an advance in the number of women with degrees in Accounting. However, the under-representation of women accountants evolved only in quantity and not on quality, which are still struggling to ascend the high positions of the accounting profession, especially as partners in audit firms. The women gender inequality in the audit has been a reflection of the personal life and care with family (DAMBRIN; LAMBERT, 2008).

Cooke and Xiao (2014) investigate the nature of the work of external auditors in China, and how the personal lives of women auditors becomes a constraint for career. They explored the probable differences in aspirations for career advancement for male and female auditors and the extent to which these differences can be reinforced by the social role of gender, organizational practices and preferences. They based their 
study on 69 interviews with five companies located auditors in China. The results indicated that women's careers as auditors are under pressure due to both the social role of gender as by the organizational factors. The gender stereotypes persist, shaping the career of auditors and determining the gender inequality in the profession.

\subsection{GLASS CEILING APPROACH}

The glass ceiling is a concept introduced in the 1980s, in the United States to describe a transparent and subtle barrier that is able to make the rise of women to the highest levels of the organizational hierarchy impossible. The barrier affects women as a group, preventing progress due to gender and not because of lack of ability to take up higher hierarchy of functions (POWELL; BUTTERFIELD, 1994; OHLOTT; RUDERMAN; MCCAULEY, 1994).

About organizations and gender, Mills (1993) states that organizations are not set up in areas where people enter, but in an entangled network of relations in which the issue of gender is deeply rooted. Thus, gender has an important aspect in interpersonal and work relationships that may impact on gender inequality, because men create barriers to the rise of women (POWELL, 1993).

Martin (1990) systematized the results of 14 studies in which the findings pointed out that women are segregated in occupational terms, unfairly assessed and paid less than men. Another line of research about the glass ceiling phenomenon analyzes the differences and similarities in professional development opportunities for men and women. Experimental studies indicate that men are less likely to delegate challenging tasks for women (OHLOTT; RUDERMAN; MCCAULEY, 1994).

The selection of professionals to occupy senior positions in the organizational hierarchy becomes complex and subjective and discrimination against women is increasingly invisible, yet active (OHLOTT; RUDERMAN; MCCAULEY, 1994). According to the glass ceiling perspective, there is possibly an invisible barrier (glass ceiling) in the accounting profession that may explain gender inequality in certain levels of the profession. According to Cooper Jackson (2001) researchers believe that the creation of the invisible barrier is closely related to gender, rather than the lack of professional capacity.

Interestingly there are activities that receive preferably men because they have aggressive characteristics, objective thinking, dominance, competition and determination (KLENKE, 1996). However, when women exhibit such characteristics often receive negative evaluation; while men displaying the same traits are evaluated 
positively. Women report that if they adopt a female management style they run the risk of being regarded as ineffective, and if they adopt a male style they will be criticized for not adopting other practices (RAGINS; TOWNSEND; MATTIS, 1998). These authors report that women feel the need to work more hours to prove credibility, particularly when they are occupying high-ranking positions.

For Leite (1994) knowledge gives women real opportunities for professional fulfillment. Knowledge can offer freedom and mobility in the labor market expanding the horizons of professional fulfillment. The business world values knowledge and therefore the people who have capacity for innovation will have opportunities to occupy positions of management and leadership. The business world of the twenty-first century requires a differentiated profile of women, a factor that can cause changes in the relations of family context. This aspect brings challenges for the post-industrial society that have to deal with gender diversity in a context of great changes, especially in the family environment (GOMES, 2005).

Morrison and Glinow (1990) comment that the glass ceiling-related obstacles prevent the advancement of women to positions of command and visibility. Thus, even if there are candidates for career advancement that have the same history, women will not have access to the same responsibilities and the same challenges as men (OHLOTT; RUDERMAN; MCCAULEY, 1994).

In accordance with Powell and Butterfield (1994) when the procedures for hiring and promotions are not standardized and have subjective criteria there is greater tendency in favor of males. Dwyer, Johnston and Miller (1996) comment that few men executives admit reject a woman on the basis of prejudice to the gender, and few disagree that women can have important managerial skill. However, they create barriers to acceptance of women in certain workplaces.

Recently the study of Ramdhony, Oogarah-Hanuman e Somir (2013) investigated the career advancement of women accountants in Mauritius. The results show that although there was an increase in the number of women in the accounting profession, they have not achieved senior management positions. They found that the glass ceiling and work-life balance conflicts have been responsible for the creation of barriers that hinder the advancement of women throughout the accountant career.

Souza, Voese and Abbas (2015) found that the young female accountants are breaking the glass ceiling in the search for progress in accounting career. In order to explore this proposition, they carried out a comparative analysis among young and mature female accountants. Data were collected from a questionnaire built based on research by Gammie et al. (2007). The sample consisted of 63 respondents trained in two higher 
education institutions in the state of Paraná. The findings indicate that the performance of female accountants is restricted to lower levels and they are still facing glass ceiling in search of career advancement. They suggest a starting point for further studies with the object of analysis the gender inequality in the accounting profession under the glass ceiling of the premise besides encouraging the practical proactive attitudes within companies in the development of working practices that are flexible for female accountants.

\section{RESEARCH METHODOLOGY}

This research as to its purpose, is characterized as descriptive. According to Hair Junior et al. (2005, p. 85), descriptive research “[...] has its structured plans that are specifically designed to measure the characteristics described in a research question.” The procedure used for data collection was through desk research of the Annual Social Information (RAIS). As for the method, the research has a quantitative approach by applying statistical techniques in data processing.

Data were collected in the Annual Social Information (RAIS), 2013 base year, available on the website of the Ministry of Labor and Employment. The audience was professionals in accounting, with a formal contract of employment in companies located in the three southern states of the country: Rio Grande do Sul, Santa Catarina e Paraná. Of the Brazilian Occupation Code (CBO) 252210 accountant occupations were selected: auditor CBO252205 and accounting assistant CBO 413110, with a total population of 81,756 observations, the sample consists of 34,886 observations.

In order to extract the said sample, information about the accounting area were first selected, later people who did not have complete higher education were excluded so that the parameters would be the same in all positions in the hierarchy studied. Then, information was extracted that gave rise to the following research variables: Gender, position, education, age, compensation, company size, time in position and unit of the federation. For the application of statistical techniques, those variables were categorized as in Table 1. 
Table 1 - Categorization of research variables

\begin{tabular}{|c|c|c|}
\hline Variables & Non metric Categorization & Metric Categorization \\
\hline \multirow{2}{*}{ GENDER } & Male & 01 \\
\hline & Female & 02 \\
\hline \multirow{3}{*}{ POSITION } & Accounting Auditor & 01 \\
\hline & Accountant & 02 \\
\hline & Accounting Assistant & 03 \\
\hline \multirow{3}{*}{ EDUCATION } & College Degree & 01 \\
\hline & Master’s Degree & 02 \\
\hline & Doctorate & 03 \\
\hline \multirow{6}{*}{ AGE } & $16-20$ & 01 \\
\hline & $21-25$ & 02 \\
\hline & $26-30$ & 03 \\
\hline & $31-40$ & 04 \\
\hline & $41-50$ & 05 \\
\hline & $>50$ & 06 \\
\hline \multirow{4}{*}{ REMUNERATION } & $<2.000,00$ & 01 \\
\hline & $2.000,00-5.000,00$ & 02 \\
\hline & $5.000,00-8.000,00$ & 03 \\
\hline & $>8.000,00$ & 04 \\
\hline \multirow{3}{*}{ COMPANY SIZE } & Small & 01 \\
\hline & Medium & 02 \\
\hline & Large & 03 \\
\hline \multirow{4}{*}{ TIME IN POSITION } & $<1$ year & 01 \\
\hline & $1-3$ years & 02 \\
\hline & 3-5 years & 03 \\
\hline & $>5$ years & 04 \\
\hline \multirow{3}{*}{ STATE } & SC - Santa Catarina & 01 \\
\hline & RS - Rio Grande do Sul & 02 \\
\hline & PR - Paraná & 03 \\
\hline
\end{tabular}

Source: the authors.

The data were analyzed by bivariate way to verify the relation/association between the variables studied. In this case, the correlation was performed using analysis software SPSS. According to Pestana and Gageiro (2000, p. 174), “[...] the intensity of the relationship can be observed through the measures of association, concordance or correlation. The various types of measures depend on the nature of the variables.” 
Thus, the correlation coefficient used was the Spearman test which is a measure of association that requires both variables present in measurement scale at least ordinal therefore applicable to the model for variables used in this study, as shown in Table 1.

Then the chi-square test was applied in order to test the frequency of the variable gender with other variables. According to Favero et al. (2009, p. 149), “The chi-square test can be used as an extension of binomial test and is applied to a sample in that the nominal variable assumes two or more categories. The test compares the observed frequencies with those expected in each category."

Finally, we applied the multiple correspondence analysis using the SPSS software, in order to identify the profile of gender on the other variables. The procedure adopted to make the correspondence analysis technique was HOMALS applied when seeking to verify the relationship between two or more nominal/ordinal variables (PESTANA; GAGEIRO, 2000).

\section{ANALYSIS OF RESULTS}

The analysis of the results was divided into three sections. The first shows the descriptive statistics of the observed variables, then the analysis of association between variables using the Spearman correlation is presented seeking the exclusion of variables that do not have significant association with gender variable, and the chi-square test to check and compare the observed and expected frequencies of the gender with each related variable (position, education, age, compensation, company size, time in position, state). Finally, we use homogeneity analysis with the application of multiple correspondence analysis technique (HOMALS) to identify the gender profile of accounting professionals and other variables.

\subsection{DESCRIPTIVE STATISTICS OF THE OBSERVED VARIABLES}

This section presents the results of descriptive statistics of the variables observed with the aim of showing the composition of the frequency of each variable. In Table 2 are initially presented the composition of the sample distributed by gender, for a total of 34,886 observations, divided into $44 \%$ for males and $56 \%$ for females. After that the distribution of positions is shown by gender, highlighting the position Accountant with the highest volume of 18,090 observations, with the predominance of males in this position. 
Table 2 - Descriptive statistics of the observed variables

\begin{tabular}{|c|c|c|c|c|c|c|}
\hline GENDER & \multicolumn{2}{|l|}{ Male } & \multicolumn{2}{|c|}{ Female } & \multicolumn{2}{|l|}{ Total } \\
\hline Notes & \multicolumn{2}{|l|}{15.239} & \multicolumn{2}{|l|}{19.647} & \multicolumn{2}{|c|}{34.886} \\
\hline$\%$ & \multicolumn{2}{|l|}{$44 \%$} & \multicolumn{2}{|l|}{$56 \%$} & \multicolumn{2}{|l|}{$100 \%$} \\
\hline Position & \multicolumn{2}{|c|}{ Accounting Auditor } & \multicolumn{2}{|c|}{ Accountant } & \multicolumn{2}{|c|}{ Accounting Assistant } \\
\hline Gender & Male & Female & Male & Female & Male & Female \\
\hline Notes & 2.346 & 1.490 & 9.471 & 9.438 & 3.422 & 8.719 \\
\hline$\%$ & $61 \%$ & $39 \%$ & $50,1 \%$ & $49,9 \%$ & $28 \%$ & $72 \%$ \\
\hline $100 \%$ & \multicolumn{2}{|l|}{3.836} & \multicolumn{2}{|l|}{18.909} & \multicolumn{2}{|c|}{12.141} \\
\hline Education & \multicolumn{2}{|c|}{ College Degree } & \multicolumn{2}{|c|}{ Master's Degree } & \multicolumn{2}{|c|}{ Doctorate } \\
\hline Gender & Male & Female & Male & Female & Male & Female \\
\hline Notes & 15.073 & 19.480 & 138 & 132 & 28 & 35 \\
\hline$\%$ & $44 \%$ & $6 \%$ & $51 \%$ & $49 \%$ & $44 \%$ & $56 \%$ \\
\hline $100 \%$ & 34.553 & & 270 & & 63 & \\
\hline
\end{tabular}

\begin{tabular}{|c|c|c|c|c|c|c|c|c|c|c|c|c|}
\hline Age & $16-20$ & & $21-25$ & & $26-30$ & & $31-40$ & & 41-50 & & $>50$ & \\
\hline Gender & Male & Female & Male & Female & Male & Female & Male & Female & Male & Female & Male & Female \\
\hline Notes & 40 & 56 & 1,296 & 2,517 & 2,886 & 5,107 & 5,208 & 7,564 & 3,460 & 3,358 & 2,349 & 1,045 \\
\hline$\%$ & $42 \%$ & $58 \%$ & $34 \%$ & $66 \%$ & $36 \%$ & $64 \%$ & $41 \%$ & $59 \%$ & $51 \%$ & $49 \%$ & $69 \%$ & $31 \%$ \\
\hline $100 \%$ & 96 & & 3,813 & & 7,993 & & 12,772 & & 6,818 & & 3,394 & \\
\hline
\end{tabular}

\begin{tabular}{lllllllll}
\hline Remuneration & $<\mathbf{2 . 0 0 0 , 0 0}$ & $\mathbf{2 . 0 0 0 , 0 0 - 5 . 0 0 0 , 0 0}$ & $\mathbf{5 . 0 0 0 , 0 0 - 8 . 0 0 0 , 0 0}$ & \multicolumn{2}{c}{$\mathbf{8 . 0 0 0 , 0 0}$} \\
\hline Gender & Male & Female & Male & Female & Male & Female & Male & Female \\
Notes & 3,725 & 8,050 & 6,571 & 8,763 & 2,521 & 1,771 & 2,422 & 1,063 \\
$\%$ & $32 \%$ & $68 \%$ & $43 \%$ & $57 \%$ & $59 \%$ & $41 \%$ & $70 \%$ & $30 \%$ \\
$100 \%$ & 11,775 & & 15,334 & & 4,292 & & 3,485 & \\
\hline
\end{tabular}

\begin{tabular}{lllllll}
\hline Company Size & Small & & Medium & \multicolumn{3}{c}{ Large } \\
\hline Gender & Male & Female & Male & Female & Male & Female \\
Notes & 4,057 & 6,718 & 3,439 & 5,099 & 7,743 & 7,830 \\
$\%$ & $38 \%$ & $42 \%$ & $41 \%$ & $59 \%$ & $49,7 \%$ & $50,2 \%$ \\
$100 \%$ & 10,775 & & 8,538 & & 15,573 & \\
\hline
\end{tabular}

\begin{tabular}{lllllllll}
\hline Time in Position & $<\mathbf{1}$ year & \multicolumn{3}{c}{$\mathbf{1 - 3}$ years } & \multicolumn{2}{c}{$\mathbf{3 - 5}$ years } & \multicolumn{2}{c}{$>$ 5 years } \\
\hline Gender & Male & Female & Male & Female & Male & Female & Male & Female \\
Notes & 3,860 & 5,917 & 3,874 & 5,727 & 2,139 & 3,047 & 5,366 & 4,956 \\
$\%$ & $40 \%$ & $60 \%$ & $40 \%$ & $60 \%$ & $41 \%$ & $59 \%$ & $52 \%$ & $48 \%$ \\
$100 \%$ & 9,777 & & 9,601 & & 5,186 & & 10,322 & \\
\hline
\end{tabular}

\begin{tabular}{lllllll}
\hline State & SC & & RS & & PR & \\
\hline Gender & Male & Female & Male & Female & Male & Female \\
Notes & 4,511 & 6,145 & 4,157 & 6,460 & 6,571 & 7,042 \\
$\%$ & $42 \%$ & $58 \%$ & $39 \%$ & $61 \%$ & $48 \%$ & $52 \%$ \\
$100 \%$ & 10,656 & & 10,617 & & 13,613 & \\
\hline
\end{tabular}

Source: the authors. 
Then the distribution of education and gender is presented demonstrating that complete higher education is the formation of the majority with 34,553 observations and predominance of females in this level of training. In the age distribution by age it is observed that the largest public lies in the range of 31 to 40 years, with 12,772 observations and there is a predominance of females in this age group.

On remuneration, its distribution shows that there is a predominance in the range of $\mathrm{R} \$ 2,000.00$ to $\mathrm{R} \$ 5,000.00$, and predominance of females in this salary range. Regarding the size of companies, it is shown that large companies make up the largest amount, with gender distributed practically equitably between male and female. With respect to time in position, the largest volume of observations is in the group with over 5 years in the position with 10,322 observations, followed very close by the group with less time than a year and that with time period of one to three years in position. Finally, it demonstrates location by state, with the state of Paraná presenting the greatest number, 13,613 observations and a small difference between females and males. This gender distribution, in percentage terms, was also very close to those found in the state of Santa Catarina, but far from gender distribution occurred in Rio Grande do Sul.

\subsection{ANALYSIS OF ASSOCIATION BETWEEN VARIABLES}

In a preliminary analysis of the application of the multiple correspondence analysis technique (HOMALS) study aimed to verify the degree of independence and association between the variables. Thus, first an exploratory data analysis by the correlation test (Spearman) was carried out and then the chi-square test in order to test the result of the correlation. The Spearman test was to identify the association between variables. Table 3 provides the measure of association between the variables. 
Table 3 - Measure of association between the variables

\begin{tabular}{|c|c|c|c|c|c|c|c|c|c|}
\hline & & (1) & (2) & (3) & (4) & (5) & (6) & (7) & (8) \\
\hline $\begin{array}{l}\text { Position } \\
\text { (1) }\end{array}$ & $\begin{array}{l}\text { Coefficient } \\
\text { / Sig. }\end{array}$ & 1.000 & $-0.020^{* *}$ & $-0.206^{* *}$ & $-0.478^{* *}$ & $0.237^{* *}$ & $-0.250^{* *}$ & $-0.179^{* *}$ & $-0.050^{* *}$ \\
\hline $\begin{array}{l}\text { Education } \\
\text { (2) }\end{array}$ & $\begin{array}{l}\text { Coefficient } \\
\text { / Sig. }\end{array}$ & & 1.000 & $0.022^{* *}$ & $0.037^{* *}$ & $-0.012^{*}$ & $0.022^{* *}$ & 0.010 & $0.045^{* *}$ \\
\hline $\begin{array}{l}\text { Age } \\
\text { (3) }\end{array}$ & $\begin{array}{l}\text { Coefficient } \\
\text { / Sig. }\end{array}$ & & & 1.000 & $0.368^{* *}$ & $-0.178^{* *}$ & $0.111^{* *}$ & $0.370^{* *}$ & $0.030^{* *}$ \\
\hline $\begin{array}{l}\text { Remuneration } \\
\text { (4) }\end{array}$ & $\begin{array}{l}\text { Coefficient } \\
\text { / Sig. }\end{array}$ & & & & 1.000 & $-0.233^{* *}$ & $0.445^{* *}$ & $0.386^{* *}$ & $0.032^{* *}$ \\
\hline $\begin{array}{l}\text { Gender } \\
\text { (5) }\end{array}$ & $\begin{array}{l}\text { Coefficient } \\
\text { / Sig. }\end{array}$ & & & & & 1.000 & $-0 . .109^{* *}$ & $-0.095^{* *}$ & $-0.056^{* *}$ \\
\hline $\begin{array}{l}\text { Company Size } \\
\text { (6) }\end{array}$ & $\begin{array}{l}\text { Coefficient } \\
\text { / Sig. }\end{array}$ & & & & & & 1.000 & $0.214^{* *}$ & $0.029^{* *}$ \\
\hline $\begin{array}{l}\text { Time in Posi- } \\
\text { tion } \\
\text { (7) }\end{array}$ & $\begin{array}{l}\text { Coefficient } \\
\text { / Sig. }\end{array}$ & & & & & & & 1.000 & $-0.043^{* *}$ \\
\hline $\begin{array}{l}\text { Federation } \\
\text { Unit } \\
\text { (8) }\end{array}$ & $\begin{array}{l}\text { Coefficient } \\
\text { / Sig. }\end{array}$ & & & & & & & & 1.000 \\
\hline
\end{tabular}

Source: the authors.

Notes: * Significance level of 5\%.

** Significance level of $10 \%$.

It is noted that the values of "sig", less than 0.05, enhance the dependence between pairs of variables. Thus, the results of the correlation test (Spearman) allow to predict that there is a significant association between the variable gender and job variables $(0.237 * *)$, education $(-0.012 *)$, age $(-0.178 * *)$, compensation $(-0.233 * *)$, company size $(-0.109 * *)$, time in position $(-0.095 * *)$ and federation unit $(-0.56 * *)$. The result of the correlation indicates that the position of accounting assistant is more associated with the female gender, lower educational level is associated with the female gender, younger age is associated with the female gender, lower pay is associated with the female gender, the smaller companies are associated with the female gender, the shortest time in position is associated with the female gender and the state of Santa Catarina and Rio Grande do Sul are more associated with females.

Moreover, the results suggest that all variables have some association with gender of the accounting profession. Therefore, observation allowed the use of all variables for the application of chi-square test. The test was used to verify the evidence of the facts presented in the correlation of Spearman, so the first verification was of gender versus position, as shown in Table 4. 
Table 4 - Chi-square test between Gender versus Time in position

\begin{tabular}{|c|c|c|c|c|c|c|c|}
\hline & & & \multicolumn{3}{|c|}{ Position } & \multirow[b]{2}{*}{ Total } & \multirow[b]{2}{*}{ Sig. } \\
\hline & & & $\begin{array}{c}\text { Accounting } \\
\text { Auditor }\end{array}$ & Accountant & $\begin{array}{c}\text { Accounting } \\
\text { Assistant }\end{array}$ & & \\
\hline \multirow{4}{*}{ Gender } & \multirow[b]{2}{*}{ Male } & Count & 2,346 & 9,471 & 3,422 & 15,239 & \\
\hline & & $\begin{array}{l}\text { Expected } \\
\text { Count }\end{array}$ & $1,675.7$ & 8,259.9 & $5,303.5$ & $15,239.0$ & \\
\hline & \multirow[b]{2}{*}{ Female } & Count & 1,490 & 9,438 & 8,719 & 19,647 & \\
\hline & & $\begin{array}{l}\text { Expected } \\
\text { Count }\end{array}$ & $2,160.3$ & $10,649.1$ & $6,837.5$ & $19,647.0$ & \\
\hline
\end{tabular}

Source: the authors.

It is observed that the test showed significance at 5\%, proving that there are differences between male and female in the matter of positions involving the accounting profession. The facts show that, on elite positions in the accounting profession, as the Accounting Auditor, the expected score for males was 1,675.7 and the actual count was 2,346; on the other hand, for females, the expected count was 2,160.30 and the effective count was 1,490 .

It is concluded that in most senior positions in the accounting profession (accounting auditor) there is a predominance to be exercised by men and not by women. The same occurs in the position of accountant where men outnumber the expected count, while women were below the expected count, further proving the facts.

Moreover, the male predominance in higher positions is also confirmed when observed the accounting assistant function, i.e., a lower hierarchy function or subordination to the professional accounting where the test results show the opposite. That is where women should have lower participation they are in larger numbers.

The results suggest that in the accounting profession the glass ceiling approach is disseminated on the issue of hierarchy and in certain work positions. The results confirm that the inferences of Morrison and Glinow (1990) on glass ceiling obstacles that prevent women to take leadership and visibility positions such as of accounting audit and accountant positions. Thus, women tend to take on less visible positions as the accounting assistant due to the existence of glass ceiling in the accounting profession.

The results show that mens have a preference to occupy supervisory positions over womens. The positions occupied by mens do not share the power and authority to womens, corroborating the findings by Marsden, Kalleberg and Cook (1993), Steil (1997), Ramdhony, Oogarah-hanuman and Somir (2013) and Souza, Voese and Abbas (2015) which prove the existence of the glass ceiling in the accounting profession.

It is concluded that the accounting profession, like other professions, has an invisible barrier that prevents access of women to jobs and occupations that offer 
higher income. The barrier affects women due to gender and not by the inability to occupy accountant and accounting auditor positions, since the training in Accounting offers and accredits professionals for the exercise of these functions (POWELL; BUTTERFIELD, 1994; OHLOTT; RUDERMAN; MCCAULEY, 1994). Further, Table 5 describes the chi-square test between Gender vs. Education.

Table 5 - Chi-square test on gender versus education

\begin{tabular}{|c|c|c|c|c|c|c|c|}
\hline & & & \multicolumn{3}{|c|}{ Education } & \multirow{2}{*}{ Total } & \multirow{2}{*}{ Sig. } \\
\hline & & & College Degree & Master's Degree & Doctorate & & \\
\hline \multirow{4}{*}{ Gender } & & Count & 15,073 & 138 & 28 & 15,239 & \multirow{4}{*}{0.047} \\
\hline & Male & $\begin{array}{l}\text { Expected } \\
\text { Count }\end{array}$ & $15,093.5$ & 117.9 & 27.5 & $15,239.0$ & \\
\hline & \multirow[b]{2}{*}{ Female } & Count & 19,480 & 132 & 35 & 19,647 & \\
\hline & & $\begin{array}{l}\text { Expected } \\
\text { Count }\end{array}$ & $19,459.5$ & 152.1 & 35.5 & $19,647.0$ & \\
\hline
\end{tabular}

Source: the authors.

It was found that the educational level showed significant differences the level of $5 \%$ between male and female genders. The results indicate that, for college degree there is a close consistency between male and female genders, what was expected and what was found (count). The same occurs at doctorate level: a certain similarity in relation to gender. However, the most relevant difference was in relation to Master's degree level, where males exceeded the expected count, and the number of females was inferior in this count, characterizing that the master degree training is predominantly made up of man. The results corroborate the National Household Sample Survey (INSTITUTO BRASILEIRO DE GEOGRAFIA E ESTATÍSTICA, 2013) which expounds on the growth of women in higher education and in the search for higher level professional specialization. Table 6 describes the chi-square test on gender versus age.

Table 6 - Chi-square test between gender versus age

\begin{tabular}{|c|c|c|c|c|c|c|c|c|c|c|}
\hline & & & \multicolumn{6}{|c|}{ Age } & \multirow{2}{*}{ Total } & \multirow{2}{*}{ Sig. } \\
\hline & & & $16-20$ & $21-25$ & $26-30$ & $31-40$ & $41-50$ & $>50$ & & \\
\hline \multirow{4}{*}{ Gender } & & Count & 40 & 1,296 & 2,886 & 5,208 & 3,460 & 2,349 & 15,239 & \multirow{4}{*}{0.000} \\
\hline & Male & $\begin{array}{l}\text { Expected } \\
\text { Count }\end{array}$ & 41.9 & $1,665.6$ & $3,491.5$ & 5,579.1 & $2,978.3$ & $1,482.6$ & $15,239.0$ & \\
\hline & \multirow[b]{2}{*}{ Female } & Count & 56 & 2,517 & 5,107 & 7,564 & 3,358 & 1,045 & 19,647 & \\
\hline & & $\begin{array}{l}\text { Expected } \\
\text { Count }\end{array}$ & 54.1 & $2,147.4$ & $4,501.5$ & $7,192.9$ & 3,839.7 & $1,911.4$ & $19,647.0$ & \\
\hline
\end{tabular}

Source: Research Data. 
It was found that the educational level showed significant differences in the level of $5 \%$ between male and female genders. The results indicate that by younger ages there is a predominance of more women in the accounting profession, wherein the levels (16-20; 21-25; 26-30; 31-40) were higher than the expected count always for females. On the other hand, the upper ages are predominance of men in the accounting profession, in which the levels of (41-50;> 50) were higher than the expected count, always for males.

The result can be explained because in the past decade women had lower participation in the labor market and in recent decades there is a greater insertion of the same in the labor market. The findings can be explained by the inference of Gomes (2005), which considers that the family environment can influence the integration of women in the labor market. In addition, the twenty-first century is beginning with a distinct profile of women that prioritize the labor market and only later seek starting a family and or having children (GOMES, 2005). Table 7 shows the chi-square test between gender versus remuneration.

Table 7 - Chi-square test between gender versus remuneration

\begin{tabular}{|c|c|c|c|c|c|c|c|c|}
\hline & & & \multicolumn{4}{|c|}{ Remuneration } & \multirow{3}{*}{ Total } & \multirow{3}{*}{ Sig. } \\
\hline & & & \multirow{2}{*}{$<2,000.00$} & $2,000.00$ & $5,000.00$ & \multirow{2}{*}{$>8,000.00$} & & \\
\hline & & & & $5,000.00$ & $8,000.00$ & & & \\
\hline \multirow{4}{*}{ Gender } & \multirow[b]{2}{*}{ Male } & Count & 3,725 & 6,571 & 2,521 & 2,422 & 15,239 & \multirow{4}{*}{0.000} \\
\hline & & $\begin{array}{l}\text { Expected } \\
\text { Count }\end{array}$ & $5,143.6$ & $6,698.2$ & $1,874.8$ & $1,522.3$ & $15,239.0$ & \\
\hline & \multirow[b]{2}{*}{ Female } & Count & 8,050 & 8,763 & 1,771 & 1,063 & 19,647 & \\
\hline & & $\begin{array}{l}\text { Expected } \\
\text { Count }\end{array}$ & $6,631.4$ & $8,635.8$ & $2,417.2$ & $1,962.7$ & $19,647.0$ & \\
\hline
\end{tabular}

Source: the authors.

It was found that the remuneration showed significant differences in the level of $5 \%$ between male and female genders. The results indicate that the higher remuneration ( $R$ \$ 5,000.00 to $R$ \$ 8,000.00 and $>R \$ 8,000.00$ ) is predominantly of men in the accounting profession and lower salaries $(<\mathrm{R} \$ 2,000.00$ and from $\mathrm{R} \$ 2,000.00$ to $\mathrm{R} \$$ $5,000.00)$ predominate among women.

The findings corroborate Stiel (1997), Guimarães (1999), Guimarães (2001) and Brighenti, Jacomossi and Silva (2015), which infer on the lower pay of women performing the same professional assignments as men. The gender gap remains significant, although women have obtained a similar education. Table 8 describes the chi-square test on gender versus company size. 
Table 8 - Chi-square test on gender versus company size

\begin{tabular}{|c|c|c|c|c|c|c|c|}
\hline & & & \multicolumn{3}{|c|}{ Company Size } & \multirow{2}{*}{ Total } & \multirow{2}{*}{ Sig. } \\
\hline & & & Small & Medium & Large & & \\
\hline \multirow{4}{*}{ Gender } & & Count & 4,057 & 3,439 & 7,743 & 15,239 & \multirow{4}{*}{0.000} \\
\hline & Male & $\begin{array}{l}\text { Expected } \\
\text { Count }\end{array}$ & $4,706.8$ & 3,729.6 & $6,802.6$ & $15,239.0$ & \\
\hline & \multirow[b]{2}{*}{ Female } & Count & 6,718 & 5,099 & 7,830 & 19,647 & \\
\hline & & $\begin{array}{l}\text { Expected } \\
\text { Count }\end{array}$ & $6,068.2$ & $4,808.4$ & $8,770.4$ & $19,647.0$ & \\
\hline
\end{tabular}

Source: the authors.

It is observed that the size of the company showed significant differences the level of $5 \%$ in relation to gender. It is concluded that there is a predominance of man in accounting of the large companies. Table 9 describes the chi-square test on gender versus time in position.

Table 9 - Chi-square test on gender versus time in position

\begin{tabular}{|c|c|c|c|c|c|c|c|c|}
\hline & & & \multicolumn{4}{|c|}{ Time in Position } & \multirow{2}{*}{ Total } & \multirow{2}{*}{ Sig. } \\
\hline & & & $<1$ year & 1-3 years & 3-5 years & $>5$ years & & \\
\hline \multirow{4}{*}{ Gender } & \multirow[b]{2}{*}{ Male } & Count & 3,860 & 3,874 & 2,139 & 5,366 & 15,239 & \multirow{4}{*}{0.000} \\
\hline & & $\begin{array}{l}\text { Expected } \\
\text { Count }\end{array}$ & $4,270.8$ & 4,193.9 & $2,265.4$ & 4,508.9 & $15,239.0$ & \\
\hline & \multirow[b]{2}{*}{ Female } & Count & 5,917 & 5,727 & 3,047 & 4,956 & 19,647 & \\
\hline & & $\begin{array}{l}\text { Expected } \\
\text { Count }\end{array}$ & $5,506.2$ & $5,407.1$ & 2,920.6 & $5,813.1$ & $19,647.0$ & \\
\hline
\end{tabular}

Source: the authors.

It was found that the time in position showed significant differences the level of $5 \%$ in relation to gender. The results show that men in the accounting profession remain in position for longer periods of time, that is, for over 5 years. This result is supported by the fact that the expected count for the gender was surpassed by actual count accounting professionals with time in position over five years. On the other hand, women predominate in all other periods of less than five years in their respective position.

These findings are corroborated by Cooper (2001) according to which women who have high positions are characterized by having a late marriage and few children. To Melamed (1995) Women's accomplishments were obtained mainly due to lack of domestic responsibilities. In addition, extensive connections with family, such as marriage and children, can lower the organizational commitment of women (MARSDEN; KALLEBERG; COOK, 1993). Table 10 shows the chi-square test of gender versus federation unit. 
Table 10 - Chi-square test on gender versus federation unit

\begin{tabular}{|c|c|c|c|c|c|c|c|}
\hline & & & \multicolumn{3}{|c|}{ State } & \multirow{2}{*}{ Total } & \multirow{2}{*}{ Sig. } \\
\hline & & & SC & RS & PR & & \\
\hline \multirow{4}{*}{ Gender } & \multirow[b]{2}{*}{ Male } & Count & 4,511 & 4,157 & 6,571 & 15,239 & \multirow{4}{*}{0.000} \\
\hline & & $\begin{array}{l}\text { Expected } \\
\text { Count }\end{array}$ & $4,654.8$ & $4,637.7$ & $5,946.5$ & $15,239.0$ & \\
\hline & \multirow[b]{2}{*}{ Female } & Count & 6,145 & 6,460 & 7,042 & 19,647 & \\
\hline & & $\begin{array}{l}\text { Expected } \\
\text { Count }\end{array}$ & $6,001.2$ & $5,979.3$ & $7,666.5$ & $19,647.0$ & \\
\hline
\end{tabular}

Source: the authors.

It is observed that the variable federation unit showed significant differences the level of $5 \%$ in relation to gender. The results indicate that women predominate in the accounting profession in greater proportion in the states of Santa Catarina and Rio Grande do Sul and that men have a higher prevalence in Paraná.

\subsection{HOMOGENEITY ANALYSIS TO TEST THE ROBUSTNESS OF FINDINGS}

Later, as a way to prove the evidence found in the chi-square test correspondence analysis was drawn up (HOMALS). Thus, it depicts the total variance explained by each dimension established, through their self-worth. It was observed the generation of two dimensions explaining respectively $30.40 \%$ and $16.60 \%$ of the data variation. Table 11 shows the discrimination measures informing about the most important variables in each dimension.

Table 11 - Discrimination measures

\begin{tabular}{lll}
\hline \multirow{2}{*}{ Variables } & Dimension & \\
\cline { 2 - 3 } & 1 & 2 \\
\hline Position & 0.448 & 0.202 \\
Education & 0.005 & 0.004 \\
Age & 0.380 & 0.424 \\
Remuneration & 0.689 & 0.447 \\
Gender & 0.172 & 0.074 \\
Company Size & 0.323 & 0.033 \\
Time in Position & 0.400 & 0.122 \\
State & 0.012 & 0.021 \\
\hline
\end{tabular}

Source: the authors.

It is verified that in the dimension 1 the most important variables refer to remuneration (0.689) and the position of the accounting profession (0.448). In addition, 
dimension 1 points to the allocation of the position (0.448), compensation (0.689), gender (0.172), size (0.323) and time in position (0.400) variables. This result meets the glass ceiling approach in which gender, position, compensation, company size and time in position variables are factors that can determine barriers for women from joining certain careers of greater prestige and power, and achieve consistent remuneration with men. In dimension 2 the most important variables were the remuneration (0.447) and age (0.424). Thus, Figure 1 shows the relationship of distribution of search categories.

Figure 1 - Correspondence distribution of the search categories

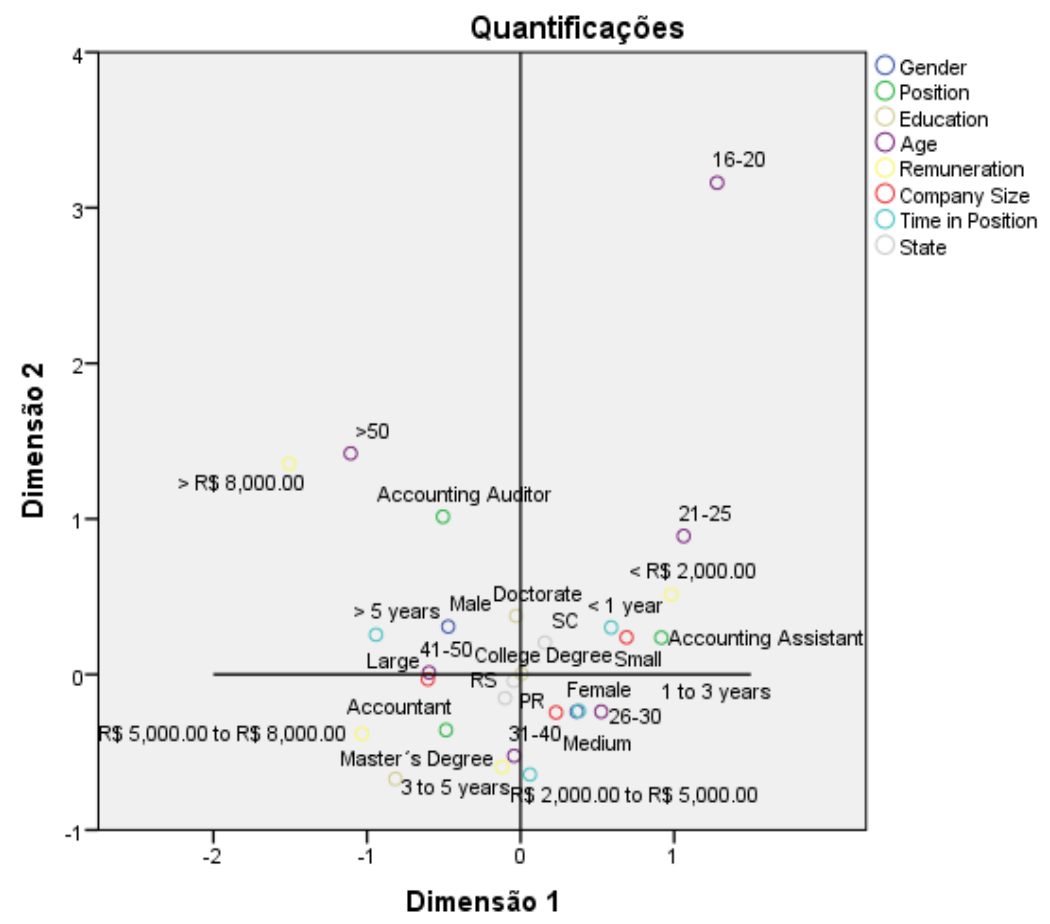

Source: the authors.

The results prove the evidence obtained by the analysis of chi-square, where the female accounting professional is closer to small and medium-sized businesses, the shortest time in the company ( 1 to 3 years), age between 26 and 30 years, in the states of Santa Catarina and Rio Grande do Sul, the position of Accounting Assistant and pay less than $\mathrm{R} \$ 2,000.00$ monthly. Already male professionals have proximity to 
higher wages, education level of doctorate, position of accounting auditor, are older, with long experience in the position.

\section{CONCLUSION}

It is found that inequality in relation to gender is part of everyday life for many professions and high-ranking management positions. The results indicate that in the accounting profession the facts are not controversial to the findings of other professional areas, there are several gender inequalities that could be observed.

We concluded that the positions of the accounting profession who are more concerned with decisions-making and non-operating are occupied by male professionals, such as the accounting auditor and accountant are considered positions of high hierarchy of the accounting profession.

Regarding education, the results indicate that the difference was more relevant in relation to the master's level in which the male gender was predominant in relation to females. Moreover, the results indicate that younger women predominate in the accounting profession. On the other hand, more advanced ages are predominantly men. It is concluded that the men of the accounting profession have most often higher remuneration than for females.

The results also show that there is a predominance of men taking the accounting profession activities in large companies and women perform such activities in small and medium size companies. And men, in most cases, stay longer in positions of the accounting profession in the same company, in relation to women.

Finally, women are working in the accounting profession in greater proportion than men in the states of Santa Catarina and Rio Grande do Sul, and the reverse occurs in Parana state where men are active in greater proportion. Therefore, the data provide information to support the evidence of the existence of glass ceiling in the accounting profession, because the results show more men in command functions and they are better paid, whereas women who are in control functions earn less and are the minority, as are women who fill most of the lower positions in business and yet they are worse paid.

The results suggest that the accounting profession in the southern region has barriers that tend to prevent women from reaching accounting positions of higher authority and/or power, such as accounting auditor and accountant. Moreover, the barrier makes accounting professionals women, even exercising similar functions to 
those of men, receive lower pay. The findings confirm the existence of the glass ceiling approach in the accounting profession.

\section{REFERÊNCIAS}

ALTOE, S. M. L. Fatores explicativos do work-life balance de contadores a luz da psicologia positiva. 2014. 136 p. Dissertação (Mestrado em Contabilidade)-Programa de Pós-graduação em Contabilidade, Universidade Federal do Paraná, Curitiba, 2014.

AVELINO JÚNIOR, F. M. Cultura da educação profissional continuada: uma análise dos contadores do Município de Fortaleza-CE. 2005. 139 p. Dissertação (Mestrado em Ciências Contábeis)-Programa Multiinstitucional e Inter-Regional de Pós-graduação em Ciências Contábeis, UnB, UFPB, UFP e UFRN, 2005.

BARRETO, M. E. D.; RYAN, M. K.; SCHMITT, M. T. The glass ceiling in the 21st century: Understanding barriers to gender equality. American Psychological Association, 2009.

BLACK, A. E.; ROTHMAN, S. Have you really come a long way? Women's access to power in the United States. Gender Issues, v. 16, i. 1-2, p. 107-133, 1998.

BRIGHENTI, J.; JACOMOSSI, F.; SILVA, M. Z. D. Desigualdades de gênero na atuação de contadores e auditores no mercado de trabalho catarinense. Enfoque: Reflexão Contábil, v. 34, n. 2, p. 109-122, 2015.

BRUSCHINI, M. C. A. Trabalho e gênero no Brasil nos últimos dez anos. Cadernos de Pesquisa, v. 37, n. 132, p. 537-572, 2007.

BRUSCHINI, M. C. A. Trabalho e gênero no Brasil nos últimos dez anos. Cadernos de Pesquisa, v. 37, n. 132, p. 537-572, 2007.

CARDOSO, J. L.; SOUZA, M. A.; ALMEIDA, L. B. Perfil do contador na atualidade: um estudo exploratório. Revista de administração e Contabilidade da Unisinos, v. 3, n. 3, p. 275-284, 2006.

CARREIRA, D.; AJAMIL, M.; MOREIRA, T. A Liderança Feminina no Século 21. São Paulo: Cortez, 2001. 
CAVALCANTI T.; GUIMARÃES J. F. Labor Market Discrimination: Quantile Regression Approach. In: ENCONTRO BRASILEIRO DE ECONOMETRIA, 21., 1999, Belém. Anais... Belém, 1999. p. 198-218.

CHERAMY, S.; HOOKS, K. Women Partners: Case Studies of Severed Relationships, CPA Journal, p. 10-16, Oct. 1988.

CIANCANELLI, P. et al. Gender and accountancy: some evidence from the UK. Critical Perspectives on Accounting, v. 1, i. 2, p. 117-144, 1990.

COOPER JACKSON, J. Women middle managers' perception of the glass ceiling. Women in Management Review, v. 16, i. 1, p. 30-41, 2001.

COOKE, F. L.; XIAO, Y. Gender roles and organizational HR practices: The case of women's careers in accountancy and consultancy firms in China. Human Resource Management, v. 53, i. 1, p. 23-44, 2014.

CRESWELL, J. W. Projeto de pesquisa: métodos qualitativo, quantitativo e misto. 3. ed. Porto Alegre: Artmed: Bookman, 2010.

DAHL, S.; HOOKS, K. Women Accountants in a Changing Profession. Journal of Accountancy, p. 108-110, 1984.

DAMBRIN, C.; LAMBERT, C. Mothering or auditing? The case of two Big Four in France. Accounting, Auditing \& Accountability Journal, v. 21, i. 4, p. 474-506, 2008.

DWYER, P.; JOHNSTON, M.; MILLER, K. L. Europe's corporate women. Business Week, v. 15, p. 40-2, 1996.

EAGLY, A. H.; JOHANNESEN-SCHMIDT, M. C.; VAN ENGEN, M. L. Transformational, transactional, and laissez-faire leadership styles: a meta-analysis comparing women and men. Psychological Bulletin, v. 129, i. 4, p. 569-591, 2003.

EARNEST, K.; LAMPE, J. Attitudinal differences between male and female auditors. Woman CPA Ouly, p. 13-20, 1992.

FÁVERO, L. P. et al. Análise de dados: modelagem multivariada para a tomada de decisões. Rio de Janeiro: Campus, 2009. 
GAMMIE, E. et al. Women of ICAS reaching the top: the demise of the glass ceiling. The Institute of Chartered Accountants of Scotland, 2007.

GOMES, A. F. O outro no trabalho: mulher e gestão. Revista de Gestão USP, São Paulo, v. 12, n. 3, p. 1-9, jul./set. 2005.

GUIMARÃES, J. F. Changes in the earning Distribution in Brazil, 1986-1995: Human Capital and Institutional Factors. In: ENCONTRO BRASILEIRO DE ECONOMETRIA, 23., 2001, Salvador. Anais... Salvador, 2001.

HAIR JUNIOR J. F. et al. Fundamentos de métodos de pesquisa em administração. Tradução Lene Belon Ribeiro. Porto Alegre: Bookman, 2005.

HOFFMANN, G. H. Responsabilidade social e a questão de gênero. Revista Fae Business, Curitiba, set. 2004.

INSTITUTO BRASILEIRO DE GEOGRAFIA E ESTATÍSTICA. Pesquisa Nacional por Amostra de Domicílios PNAD 2013. Available from: <www.ibge.gov.br>. Access on: Feb. 192016.

KLENKE, K. Women and Leadership: a contextual perspective. New York: Springer, 1996.

LEITE, C. L. de P. Mulheres: muito além do teto de vidro. São Paulo: Atlas, 1994.

LEHMAN, C. R. Herstory in accounting: The first eighty years. Accounting, Organizations and Society, v. 17, i. 3, p. 261-285, 1992.

MARSDEN, P. V.; KALLEBERG, A. L.; COOK, C. R. Gender differences in organizational commitment influences of work positions and family roles. Work and Occupations, v. 20, i. 3, p. 368-390, 1993.

MARTIN, J. Deconstructing organizacional taboos: the supression of gender conflict in organizations. Organization Science, v. 1, i. 4, p. 339-359, 1990.

MCKEEN, C. A.; RICHARDSON, A. J. Education, employment and certification: an oral history of the entry of women into the Canadian accounting profession. Business and Economic History, v. 27, i. 2, p. 500-521, 1998.

MELAMED, T. Career success: The moderating effect of gender. Journal of Vocational Behavior, v. 47, i. 1, p. 35-60, 1995. 
MEYERSON, D. E.; FLETCHER, J. K. A modest manifesto for shattering the glass ceiling. Harvard Business Review, v. 78, i. 1, p. 126-136, 2000.

MORRISON, A.; GLINOW, M. Womem and minorities in management. American Psychologist, v. 45, i. 2, p. 200-208, 1990.

MUNHOZ, G. de S. Quais as contribuições que o estilo feminino de liderança traz para as organizações empreendedoras? In: ENCONTRO NACIONAL DE EMPREENDEDORISMO, 2000, Maringá. Anais... Maringá: EGEPE, out. 2000. p. 164-176.

OAKLEY, J. G. Gender-based barriers to senior management positions: understanding the scarcity of female CEOs. Journal of Business Ethics, v. 27, i. 2, p. 321-35, 2000 .

OHLOTT, P. J.; RUDERMAN, M. N.; MCCAULEY, C. D. Gender differences in managers' developmental job experiences. Academy of management Journal, v. 37, i. 1, p. 46-67, 1994.

OLIVEIRA, J. S. de (Org.). O traço da desigualdade social brasileira. Rio de Janeiro: IBGE, 1993.

PESTANA, M. H.; GAGEIRO, J. N. Análise de dados para ciências sociais: a complementaridade do SPSS. 2. ed. Lisboa: Sílabo, 2000.

PILLSBURY, C.; CAPOZZOLI, L.; CIAMPA, A. A Synthesis of research studies regarding the upward mobility of women in public accounting. Accounting Horizons, p. 63-70, 1989.

POWELL, G. Women \& men in management. 2. ed. Newbury Park: Sage, 1993.

POWELL, G.; BUTTERFIELD, D. A. Investigating the glass-ceiling phenomenon: an empirical study factual promotion to top management. Academy of Management Journal, v. 37, i. 1, p. 68-86, 1994.

RAGINS, B. R.; TOWNSEND, B.; MATTIS, M. Gender gap in the executive suíte: CEOs and female executives report on breaking the glass ceiling. Academy of Management Executive, v. 12, i. 1, p. 28-42, 1998. 
RAMDHONY, D.; OOGARAH-HANUMAN, V.; SOMIR, N. Career progression of women in accounting: the Case of Mauritius. International Journal of Humanities and Applied Sciences (IJHAS), v. 2, i. 1, p. 22-28, 2013.

RELATÓRIO ANUAL DE INFORMAÇÕES SOCIAIS. 2013. Available from: $<$ http://portal.mte.gov.br/>. Access on: Jan 62016.

RIDGEWAY, C. L. Sex, status, and leadership. Journal of Social Issues, v. 57, i. 4, p. 637-55, 2001.

ROBERTS, J.; COUTTS, J. A. Feminization and professionalization: a review of an emerging literature on the development of accounting in the United Kingdom. Accounting, Organizations and Society, v. 17, i. 3, p. 379-395, 1992.

SANTOS, R. V.; RIBEIRO, E. P. Diferenciais de rendimentos entre homens e mulheres no Brasil revisitado: explorando o "teto de vidro". Centro Universitário Newton Paiva/MG e PPGE/UFRGS, 2006.

SILVA, M. B. de; GRIGOLO, T. M. Metodologia da pesquisa e elaboração de dissertação. 4. ed. Florianópolis: Edufsc, 2002.

SIQUEIRA, I. P. et al. A inserção da mulher como profissional contábil nos escritórios de contabilidade de Tangará da Serra-MT. Revista UNEMAT de Contabilidade, v. 2, n. 3, 2013.

SOUZA, F. M. D.; VOESE, S. B.; ABBAS, K. Mulheres no topo: as contadoras paranaenses estão rompendo o glass ceiling? Advances in Scientific and Applied Accounting, v. 8, n. 2, p. 244-270, 2015.

STEIL, A. V. Organizações, gênero e posição hierárquica-compreendendo o fenômeno do teto de vidro. Revista de Administração da Universidade de São Paulo, v. 32, n. 3, 1997.

STELTER, N. Z. Gender differences in leadership: current social issues and future organizational implications. Journal of Leadership Studies, v. 8, i. 4, p. 88-100, 2002.

TRAPP, M.; HERMANSON, R.; TURNER, D. Current Perceptions of Issues Related to Women Employed in Public Accounting. Accounting Horizons, p. 71-85, 1989. 
How to mention this paper:

\section{ABNT:}

SILVA, Júlio César; MAGRO, Cristian Baú Dal; SILVA, Marcia Zanievicz da. Gender inequality in accounting profession from the perspective of the glass ceiling.

RACE, Revista de Administração, Contabilidade e Economia, Joaçaba: Ed. Unoesc, v. 15, n. 2, p. 447-474, maio/ago. 2016. Available from: <http://editora.unoesc. edu.br/index.php/race>. Access on: month/day/year.

\section{APA:}

Silva, J. C., Magro, C. B., \& Silva, M. Z. (2016). Gender inequality in accounting profession from the perspective of the glass ceiling. RACE, Revista de Administração, Contabilidade e Economia, 15(2), 447-474. Retrieved from http://editora. unoesc.edu.br/index.php/race 
